Digital Electronics

Through

Worked Examples 


\section{Other Macmillan titles of related interest}

B. R. Bannister and D. G. Whitehead, Fundamentals of Modern Digital Systems, second edition

M. Beasley, Reliability for Engineers - An Introduction

G. B. Clayton, Data Converters

J. C. Cluley, Interfacing to Microprocessors

J. C. Cluley, Introduction to Low Level Programming for Microprocessors

J. C. Cluley, Transducers for Microprocessor Systems

A. B. Fontaine and F. Barrand, 80286 and 80386 Microprocessors - New $P C$ architectures

M. Goodge, Analog Electronics

B. A. Gregory, An Introduction to Electrical Instrumentation and Measurement Systems, second edition

R. Holland, Microcomputer Fault-finding and Design

P. Jaulent, The 68000 - Hardware and Software

P. Jaulent, L. Baticle and P. Pillot, 68020/68030 Microprocessors and their Coprocessors

P. A. Lynn, An Introduction to the Analysis and Processing of Signals

R. J. Mitchell, Microcomputer Systems Using the STE Bus

N. M. Morris, Microprocessor and Microcomputer Technology

C. Walls, Programming Dedicated Microprocessors 


\section{Digital Electronics Through Worked Examples}

Norman Bonnett

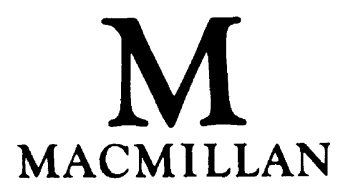


(C) N. D. Bonnett 1992

All rights reserved. No reproduction, copy or transmission of this publication may be made without written permission.

No paragraph of this publication may be reproduced, copied or transmitted save with written permission or in accordance with the provisions of the Copyright, Designs and Patents Act 1988, or under the terms of any licence permitting limited copying issued by the Copyright Licensing Agency, 90 Tottenham Court Road, London W1P 9HE.

Any person who does any unauthorised act in relation to this publication may be liable to criminal prosecution and civil claims for damages.

First published 1992 by MACMILLAN EDUCATION LTD

Houndmills, Basingstoke, Hampshire RG21 2XS and London

Companies and representatives

throughout the world

ISBN 978-1-349-11873-1

ISBN 978-1-349-11871-7 (eBook)

DOI 10.1007/978-1-349-11871-7

A catalogue record for this book is available from the British Library. 


\section{Contents}

Preface ix

Acknowledgements $\quad$ xi

1 BASIC DIGITAL THEORY 1

Q.1.1 Basic gates 1

Q.1.2 Pulse parameters 4

Q.1.3 J-K flip-flops

Q.1.4 NAND gates and catalogues 10

Q.1.5 Karnaugh maps and deMorgan 11

Q.1.6 A-D/D-A converters 14

$\begin{array}{lll}\text { Q.1.7 Counting circuits } & 17\end{array}$

2 MANUFACTURER'S DATA 24

$\begin{array}{ll}\text { Prior knowledge } & 24\end{array}$

Introduction $\quad 24$

Q.2.1 The logic gate families 25

Q.2.2 The 7400 and its data sheet 28

Q.2.3 The 7476 and 74LS76 J-K flip-flops 35 
Q.2.4 The 74194 as a modem transmitter and receiver 40

Q.2.5 The 74151A as a multiplexer 47

Q.2.6 Using the 74143 as a counter 52

Q.2.7 Counters using MSI devices 56

Q.2.8 A binary rate multiplier using the $749770 \quad 65$

Q.2.9 A keyboard encoder 66

Q.2.10 Basic RAM configurations 69

Q.2.11 The CYM1421 as a 1 Mbit RAM 73

$\begin{array}{lll}\text { Q.2.12 PROMs, ARRRAYs and ASICs } & 78\end{array}$

3 SYSTEM DESIGN $\quad 84$

$\begin{array}{ll}\text { Prior knowledge } & 84\end{array}$

Introduction $\quad 84$

Q.3.1 Present state/next state and transition diagrams 85

Q.3.2 Designing a mod-6 counter 91

Q.3.3 A BCD decade counter design 102

Q.3.4 Designing a sequence detector 105

$\begin{array}{lll}\text { Q.3.5 Hazards and races } & 112\end{array}$

4 TRANSMISSION OF DIGITAL SIGNALS 118

Q.4.1 The RS232C data system 118

Q.4.2 Distortion in pulses and its effects on gates 122

Q.4.3 Using parity bits and codes in data transmission 128 
5 SIGNAL PROCESSING 138

$\begin{array}{ll}\text { Prior knowledge } & 138\end{array}$

Q.5.1 Parameters affecting A-D converters 138

Q.5.2 A D-A converter using the ZN436E 143

Q.5.3 Using the ZN435 as a ramp and compare converter 148

Q.5.4 Data acquisition sytems 151

Q.5.5 Multiplexing and the ZN437 154

Q.5.6 Interconnecting logic families 159

6 DESIGNING SYSTEMS 166

6.1 Introduction 166

6.2 Designing systems and systems analysis 167

The technical specification in practice 171

$\begin{array}{ll}\text { Documenting a design } & 178\end{array}$

$\begin{array}{ll}\text { Teamwork and design } & 179\end{array}$

$\begin{array}{lll}\text { Q.6.1 A design example } & 182\end{array}$

$\begin{array}{lll}\text { Appendix } 1 & \text { Open collector gates } & 187\end{array}$

$\begin{array}{lll}\text { Appendix } 2 & \mathrm{~J} \text { and } \mathrm{N} \text { device outlines } & 189\end{array}$ 


\section{Preface}

There are available many excellent textbooks on both analogue and digital electronics; these range from elementary texts that cover the subject at school level (with a mainly practical approach) to those that are highly advanced and at the fringe of the technologies. It is intended that this book will strike a balance between these two extremes.

This book is intended for first and second year students of electrical and electronic engineering, in particular those studying for Higher National Certificates and Diplomas; it will also be valuable for undergraduates and should complement lecture and other source material. The aim is to enable the student to solve real world problems in a systematic and professional way.

There is a wind of change in engineering education at the moment. It is no longer sufficient to treat engineers and technician engineers simply as the recipients of information, subject them to a heavy diet of lectures, and then demand them to regurgitate these facts in an examination room. In the United Kingdom there is also pressure firstly to move away from conventional laboratory work (where the only decision that generations of students have had to make is whether to have the graph paper vertical or horizontal or what scales to use for the axis;) by moving towards assignment work. Secondly there is pressure to improve the efficiency of the teaching and lecturing process. For too long it has been believed that engineers and technician engineers are an odd body, who unlike other students appear only to be able to receive information when they are lectured to; unlike other students who can obtain and absorb information from source material! Of course this is quite untrue. A student centred approach consistently produces results that are of a higher quality, are easier to transfer to other situations, and more 
thoroughly learned than those obtained by conventional rote learning.

The approach adopted in this book is that of worked examples, using both the traditional examination question and also assignments that are based both on laboratory work and on literature searches; these latter types of examples use manufacturers' data as the prime source. There is no attempt either to choose, or of choice to ignore, devices at the forefront of technology; a thorough knowledge of the characteristics of key devices is more transferable to new products than a nodding acquaintance with every device in a data book. It is this quality of transferring knowledge from known situations to new and concrete situations that is the hall mark of sound learning. 


\section{Acknowledgements}

I would like to thank the following manufacturers for being allowed to use information from their data books and catalogues.

Texas Instruments for extracts concerning the following devices: 7400, 7473, 7476, 74LS76A, 7490, 7493A, 7497, 74143, 74LS139A, 74151, 74161A, 74180, 74194 and TBIBPPAL16LB.

Cypress Semiconductors for extracts on the following device:

CYM1421

Plessey Semiconductors for extracts on the following devices:

ZN426E, ZN435 and ZN437.

RS Components for extracts on the following device: RS74C922 and for the pin-outs for the RS232C line drivers and receivers.

I must acknowledge the help I have received from Malcolm Stewart and his team at Macmillan Education for the very helpful and patient advice and help they have given me.

Thanks also go to the people whose hardware and software I bought and used to produce the book; Amstrad for their PC1640 computer, Digital Research for the GEM drawing package, Timeworks for their DTP system and MicroPro for their Wordstar word processing package. All performed perfectly.

Ben Bennett at The Polytechnic Huddersfield ran the HILO simulations for me, and the students there and at Bradford College provided me with the initial encouragement to pursue the line of teaching 
xii

and assessment that this book uses; all have my thanks.

Last, and by no means least I must acknowledge the support of my wife Annedore. She tolerated my moods, my irregular hours at the keyboard and shared my joys. Danke Liebste. 
TO ANNEDORE 